Edukids volume 17 (1) tahun 2020

EDUKIDS: Jurnal Pertumbuhan, Perkembangan, dan Pendidikan Anak Usia Dini

Jln. Dr. Setiabudhi No. 229 Kota Bandung 40154. e-mail: edukid@upi.edu

website: http://ejournal.upi.edu/index.php/edukid

\title{
UPAYA GURU DAN ORANG TUA DALAM MENGANTISIPASI PENYELENGGARAN TES BACA TULIS
}

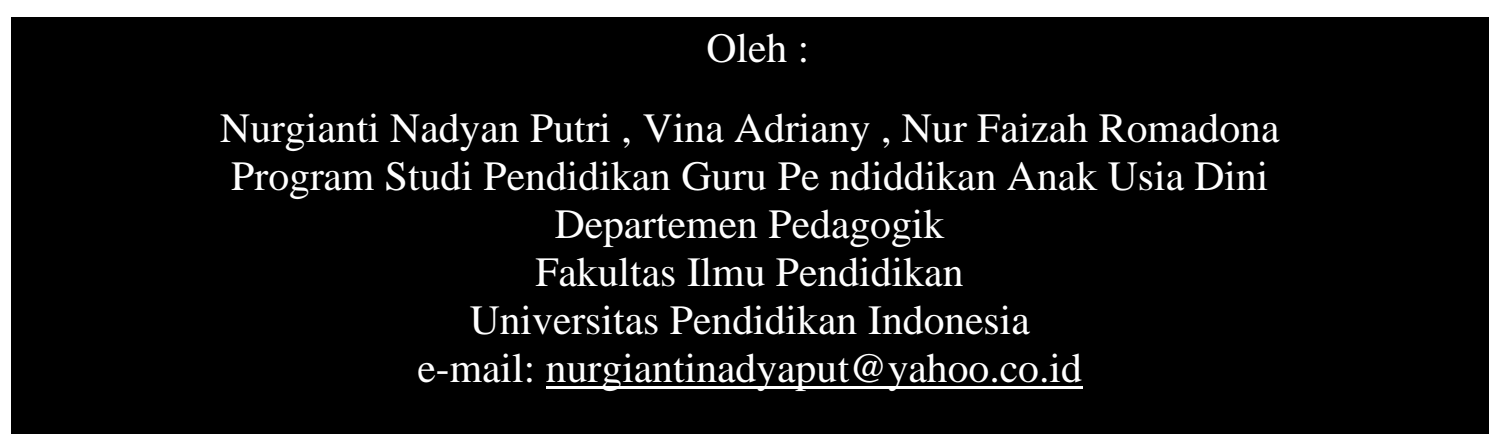

Abstrak: Tujuan penelitian ini adalah untuk mengetahui upaya guru PAUD dan orang tua dalam mengantisipasi penyelenggaraan tes baca tulis Desain peneletian ini adalah studi kasus. Maraknya penyelenggaraan tes membaca dan menulis di sekolah dasar dalam beberapa tahun terakhir ini, sebagai syarat penerimaan siswa baru. Adanya ketidak selarasan antara penyelenggaraan test baca tulis di sekolah dasar dengan kurikulum PAUD. Adanya upaya antasipasi orang tua terhadap penyelenggaran test baca tulis di sekolah dasar yaitu: dengan adanya penyelenggaran test baca tulis di sekolah dasar ini menjadi memberatkan orang tua, di sisi lain itu menjadi sesuatu kewajiban. Orang tua tidak mempunyai pilihan lain, untuk hal itu orang tua mempunyai strategi tersendiri dengan memperkenalkan buku cerita dan membiasakan untuk dibacakan buku cerita sebelum tidur,. Begitupun dengan upaya guru PAUD mengantisipasi terhadap penyelenggaran test baca tulis di sekolah dasar dengan membiasakan setiap minggunya dibacakan cerita melalui cerita bergambar dan mengajarkan calistung menggunakan metode cantol roudhoh.

\section{Kata Kunci : Calistung, Sekolah Dasar, Ujian Masuk Sekolah.}

Abstract: The purpose of this study was to determine the efforts of PAUD teachers and parents in anticipating the implementation of the literacy test. The research design was a case study. The rise of the implementation of reading and writing tests in elementary schools in recent years, as a condition of admission of new students. There is a disharmony between the implementation of reading and writing tests in elementary schools and the PAUD curriculum. There is an effort to anticipate parents against the organization of literacy tests in elementary schools, namely: with the holding of literacy tests in elementary schools, this becomes burdensome for parents, on the other hand it becomes something obligatory. Parents have no other choice, for that parents have their own strategy by introducing story books and getting used to reading story books before going to bed. Likewise with the efforts of PAUD teachers to anticipate the implementation of literacy tests in elementary schools by getting used to reading stories every week through picture stories and teaching calistung using the cantol roudhoh method..

Keywords: Calistung, Elementary School, School Entrance Test 


\section{PENDAHULUAN}

Salah satu perkembangan anak usia dini adalah perkembangan keaksaraan atau perkembangan literasi. Sebagai fasilitator dalam perkembangan literasi anak di sekolah, guru mewujudkannya dalam pembelajaran yang menyenangkan di sekolah yang nantinya mampu menumbuhkan minat anak terhadap sesuatu, salah satunya minat anak dalam literasi. Maka, peran guru di sekolah diharapkan secara alamiah mampu memberikan hubungan yang positif dan menumbuhkan rasa percaya diri serta minat anak (Watson dan Wildy, 2014).

Literasi adalah proses membaca, menulis, berbicara, mendengarkan, melihat dan berpendapat (Kuder dan Hasit, 2002). Literasi secara umum didefinisikan sebagai kemampuan membaca dan menulis serta menggunakan bahasa lisan. Perkembangan literasi pada anak prasekolah berada pada tahap literasi dasar. Anak-anak prasekolah sering kali terlihat mencorat-coret kertas atau bahkan dinding dengan huruf-huruf atau angka namun masih kurang jelas dan kurang tertata. Kuder dan Hasit (2002) menjelaskan bahwa pertama kali anak-anak memegang sebuah buku atau pensil melihat orang dewasa membaca atau menulis, atau melihat papan nama rumah makan, maka anak tersebut sedang belajar sesuatu tentang literasi. National Intitutes of Children and Human Development menjelaskan bahwa literasi dini dalah kemampuan membaca dan menulis seelum anak benar-benar mampu membaca dan menulis. Perkembangan literasi pada anak prasekolah berada pada tahap literasi dasar. Kemampuan literasi bukanlah kemampuan yang dimiliki anak seiring dengan pertambahan usia tetapi kemampuan yang dimiliki. Sehingga dapat disimpulkan bahwa perilaku anak-anak tersebut telah menunjukkan adanya tahap literasi dasar. Kemampuan literasi atau kemampuan berkomunikasi pada anak akan mempengaruhi perkembangan sosial, emosi dan perkembangan kognitifnya. Jika anak mampu berkomunikasi dengan lingkungan sekitar maka akan tumbuh kepercayaan diri dan mampu bersosialisasi atau bisa diterima di lingkungannya. Kemampuan berbahasa mempengaruhi penyesuaian sosial dan pribadi anak tentu akan mempengaruhi pula perkembangan emosi dan kognitifnya (Hurlock, 1978, hlm. 178).

Pemerintah Indonesia sekarang ini sedang mencoba meningkatkan perkembangan literasi pada anak. Perkembangan literasi saat ini sangat pesat, literasi diartikan sebagai kemampuan membaca dan menulis. Berdasarkan World Economic Forum (2016) disepakati bahwa terdapat enam literasi dasar yang sangat penting, tidak hanya bagi pelajar tetapi juga bagi seluruh masyarakat, enam literasi dasar itu meliputi literasi baca tulis, literasi numerasi, literasi sains, literasi digital, literasi finansial, dan literasi budaya dan kewarganegaraan. Dalam penelitian ini literasi difokuskan pada literasi baca tulis karena literasi baca tulis ini mempunyai peran penting dalam literasi, salah satunya mengenai pemahaman konsep literasi pada anak usia dini, karena literasi dasar ini menjadi literasi yang bisa dikembangkan sejak dini (Ananto, 2019). 
Pada kenyataannya di lapangan ditemukan kemampuan literasi pada anak usia dini masih sangat memprihatinkan. Hasil survei internasional, yaitu Progress in International Reading Literacy Study (PIRLS) (2011), serta Programme for International Student Assessment (PISA) (2009 dan 2012), menunjukkan bahwa keterampilan membaca siswa Indonesia masih berada di urutan ke 57 dari 65 negara. Fakta ini membuka mata kita semua bahwa kemampuan literasi siswa Indonesia masih rendah. Kurangnya minat baca anak menjadi salah satu penyebab lemahnya kemampuan dalam berliterasi. Hal tersebut menyebabkan lemahnya kemampuan membaca siswa di Indonesia, kemampuan membaca anak sekolah dasar di Indonesia menempati urutan ke-38 dari 39 negara ASEAN (Santoso, 2011).

Selain hasil di atas membuktikan bahwa minat baca di Indonesia masih tergolong rendah. Dapat dibuktikan dari data lainnya yang di dapat dari hasil survei nasional oleh UNESCO yang menjelaskan tingkat melek huruf dalam hitungan Indeks Kesetaraan Gender (GPI) yang membagi angka melek huruf antara perempuan dan laki-laki. Pada tahun 2011 dengan jumlah laki-laki dan perempuan berusia sekitar 15 tahun yang menunjukkan angka melek huruf hanya $0,94 \mathrm{GPI}$, dan populasi melek huruf yang dinyatakan dalam persen hanya 69,7 persen. Terbukti bahwa minat baca di Indonesia masih tergolong rendah dengan adanya hasil penelitian tersebut (UNESCO Institute for Statistics, 2013: 43).

Fakta-fakta tersebut bukanlah berita yang baik bagi bangsa kita.
Padahal kegiatan membaca juga kegiatan utama dalam pendidikan dan buku merupakan investasi masa depan, perilaku gemar membaca hendaknya ditumbuhkan sejak dini pada anak agar anak tersebut merasa tertarik dan memiliki minat yang tinggi terhadap membaca karena penanaman budaya baca akan lebih sulit bila diterapkan jika anak tumbuh dewasa . (Suwardi, 2007).

Literasi dini sangat bermanfaat untuk perkembangan kebahasaan anak khususnya pada kemampuan membaca dan menulis. Meskipun kemampuan literasi membaca dan menulis sangat penting untuk anak, akan tetapi saat ini khususnya dikalangan PAUD terdapat pro dan kontra terkait dengan kedua kemampuan tersebut (Murtie, 2013). Ada yang berpendapat bahwa mengajarkan membaca dan menulis pada anak usia ini itu sangat penting. Salah satu yang di inginkan dari setiap orang tua itu agar anak bisa membaca dan menulis sebelum anak memasuki jenjang Sekolah Dasar (Murtie, 2013). Akan tetapi di sisi lain ada yang berpendapat bahwa mengajarkan membaca dan menulis pada anak usia dini itu sangat penting dan ada pula orang tua yang berpendapat bahwa membaca dan menulis pada anak usia dini itu berdampak negatif pada anak. Salah satu alasan yang menyebabkan beberapa orang tua berpendapat bahwa mengajarkan membaca dan menulis pada anak usia dini itu berdampak negatif adalah karena adanya anggapan bahwa anak belum dapat berfikir secara konkret (Piaget, 1988, hlm. 139). Disamping itu terdapat kekhawatiran anak-anak menjadi terbebani dan tujuan awal 
untuk mencerdaskan anak itu menjadi tidak tercapai karena justru anak-anak menjadi tidak bahagia dan tidak bisa menikmati kehidupan mereka. Pandangan ini didukung oleh pendapat dari Piaget yang menyatakan bahwa di usia tujuh tahun itu anak berada pada tahapan praoperasional konkret dimana kemampuan anak untuk mengingat dan berfikir secara logis itu masih terbatas (Piaget, 1988, hlm. 146). Hal ini yang menjadi membingungkan bagi orang tua maupun guru yang ingin mengembangkan potensi intelektual anaknya tanpa harus menunggu usia 7 tahun (Desmita, 2012, hlm. 12).

Permasalahan yang ada dalam literasi pada anak usia dini saat ini yaitu mengenai pemahaman antara guru PAUD dan orang tua karena sehubungan dengan adanya larangan dari Kementrian Pendidikan dan Kebudayaan telah melarang sekolah dasar untuk menggelar tes baca sebagai standar penerimaan siswa baru. Namun pada faktanya banyak sekolah dasar khususnya di kota bandung yang menggelar tes membaca dan menulis untuk menjadi standar penerimaan siswa baru, sehingga orang tua menuntut lembaga TK atau PAUD untuk mengajarkan anak dalam membaca dan menulis (Hidayat, 2016).

Banyak orang tua yang memberikan jam tambahan di luar sekolah untuk bimbingan belajar membaca dan menghitung dengan tujuan agar anaknya bisa masuk jenjang Sekolah Dasar (Fajriyah, 2018). Tetapi guru di lembaga TK atau PAUD ini khawatir untuk mengajarkan literasi pada anak sejak dini karena Dinas Pendidikan melarang untuk mengajarkan pembelajaran menulis dan menghitung anak usia dini karena anak belum waktunya untuk mencapai perkembangan tersebut (Fajriyah, 2018, hlm. 166).

Berdasarkan uraian sebelumnya yang menyatakan bahwa adanya pro dan konra antara guru dan orang tua mengenai sehubungan dengan adanya larangan dari pihak Kementrian Pendidikan dan Kebudayaan serta Peraturan Pemerintah melarang untuk menggelar tes membaca dan menulis untuk menjadi standar penerimaan siswa baru sekolah dasar. Tetapi pada kenyataannya masih banyak kesalahpahaman pada kalangan akademis sekolah dasar yang mensyaratkan bagi calon siswa yang akan masuk itu diharuskan lulus tes baca tulis. Banyak orang tua selalu mengusahakan anaknya untuk bisa belajar membaca, menulis dan berhitung sebelum mereka memasuki sekolah dasar.

Berdasarkan pemaparan diatas yang menyatakan adanya pro konta mengenai literasi baca tulis pada anak usia dini. Maka peneliti tertarik untuk melihat lebih jauh bagaimana sesungguhnya pandangan guru dan orang tua mengenai konsep literasi baca tulis pada pendidikan anak usia dini.

\section{METODE}

Penelitian ini menggunakan pendekatan kualitatif. Dalam penelitian kualitatif ini mencoba mengerti makna suatu kejadian atau peristiwa dengan mencoba berinteraksi dengan orang-orang dalam situasi atau fenomena tersebut (Yusuf, 2014. Hlm. 328). Metode kualitatif berusaha mengungkapkan berbagai keunikan yang terdapat dalam individu, kelompok, 
masyaratakat, organisasi dalam kehidupan sehari-hari secara menyeluruh, rinci, dalam dan dapat dipertanggung jawabkan secara ilmiah Miles dan Huberman ( dalam Basrowi dan Suwandi, 2008, hlm. 22). Penelitian berfokus pada upaya guru dan orang tua dalam mengantisipasi penyelanggaraan tes baca tulis di sekolah dasar, sehingga peneliti memilih desain penelitian studi kasus. Penelitian kualitatif ini adalah dengan berfokus pada jenis data actual dan prosedur pengumpulannya. Data dari penelitian disajikan dalam bentuk deskriptif bersumber dari datayang telah dikumpulkan berupa hasil wawancara. Berdasarkan hal tersebut pendekatan kualitatif dengan desain penelitian studi kasus dipilih karena peneliti bermaksud untuk melihat upaya antisipasi guru PAUD dan orang tua mengenai adanya tes penyelenggaraan baca tulis di sekolah dasar.

\section{HASIL DAN PEMBAHASAN}

Pada pembahasan ini akan diuraikan tentang analisis temuan penelitian. Analisis dilakukan dengan mengacu pada berbagai teori yang mendukung temuan-temuan tersebut. Uraian ini sekaligus berfungsi sebagai jawaban atas pertanyaan penelitian yang telah ditetapkan sebelumnya sebagai berikut:

1. Apa yang ibu pahami mengenai literasi pada pendidikan anak usia dini ?

2. Seberapa pentingkah literasi baca tulis pada anak usia dini?

3. Apa pandangan ibu mengenai adanya penyelenggaraan tes baca tulis di sekolah dasar pada pendidikan anak usia dini?

\begin{abstract}
Uraian berikut akan menjelaskan tentang ketiga pertanyaan penelitian terdapat dua sub-tema, yaitu : 1) Ketidak Selarasan Antara Kurikulum PAUD dan Kurikulum Sekolah Dasar, 2) Negosiasi Orang Tua Terhadap Tes Baca Tulis di Sekolah Dasar, 3) Negosiasi Guru PAUD Terhadap Tes Baca Tulis di Sekolah Dasar.
\end{abstract}

\section{Ketidak Selarasan Antara Penyelenggaraan Tes Baca Tulis di Sekolah Dasar dengan Kurikulum PAUD}

Pada bagian ini peneliti akan membahas mengenai adanya ketidak selarasan antara penyelenggaraan tes baca tulis dengan kurikulum PAUD, dengan penyelenggaraan tes baca tulis di sekolah dasar, menunjukkan adanya ketidak selarasan kurikulum PAUD dengan penyelenggaraan tes baca tulis di sekolah dasar. Mengapa demikian, karena dalam kurikulum PAUD dan pada hakikatnya anak di bawah enam tahun itu berada pada masannya bermain, dimana anak memiliki karakteristik yang berbeda dengan orang dewasa dalam berperilaku. Dengan demikian dalam hal belajar anak juga memiliki karakteristik yang tidak sama dengan orang dewasa. Maka dari itu anak di bawah enam tahun merupakan usia yang sangat menentukan dalam pembentukan karakter dan kepribadian anak (Sujiono, 2013: 7). Berdasarkan data penelitian, bahwa terdapat penyelenggaran tes baca tulis di sekolah dasar, tidak sedikit sekolah dasar favorit yang menerapkan aturan anak yang mendaftar di SD itu sudah harus bisa membaca, menulis dan berhitung, sehingga, orang tua banyak berharap di TK maupun PAUD sudah mulai diajarkan tentang calistung. 
Akan tetapi bisa lihat untuk memasuki sekolah dasar itu calon peserta didik harus mengikuti tes baca tulis, hal ini menjadikan guru PAUD dan orang tua harus mempersiapkan anaknya untuk bisa baca tulis sebelum memasuki jenjang sekolah dasar, yaitu dengan menambah jam belajar anak, tetapi untuk itu tidak akan menjadi sesuatu hal yang positif, jika pemberian calistung diberikan secara terburu-buru atau karena adanya keterpaksaan, sehingga tidak memperhatikan kondisi mental dan perkembangan anak (Pratiwi, 2015).

Guru mengatakan bahwa dalam perkembangan anak usia dini, anak masih memahami dalam pemahaman konsep dasar saja. Begitu pula untuk pemahaman baca tulis atau bisa dikatakan dengan literasi, dalam pemahaman mengenai literasi anak baru memulai pemahaman dalam bahasanya saja.

Dari pernyataan tersebut, maka dapat dikatakan bahwa dalam penyelenggaraan tes baca tulis di sekolah dasar ini adanya ketidak selarasan antara kurikulum PAUD dan bertolak belakang dengan kurikulum PAUD sendiri, dikarenakan untuk pemberian rangsangan dalam pembelajaran pada pendidikan anak usia dini (PAUD) melalui cara yang tepat, yaitu melalui pembelajaran dengan bermain, dengan memberikan pembelajaran yang bermakna bagi anak untuk kesiapan mental atau pembentukan karakter dasar dalam memasuki jenjang pendidikan lebih lanjut. Hal ini sejalan dengan UU Nomor 20 Tahun (2003 Bab I Pasal 1 Ayat 14 ) yaitu "Pendidikan anak usia dini adalah suatu upaya pembinaan yang ditujukan kepada anak sejak lahir sampai dengan usia enam tahun yang dilakukan melalui pemberian rangsangan pendidikan untuk membantu pertumbuhan dan perkembangan jasmani dan rohani agar anak memiliki kesiapan dalam memasuki pendidikan lebih lanjut."

\section{Negosisasi Orang Tua Terhadap Tes Baca Tulis di Sekolah Dasar}

Berbicara mengenai calistung, untuk calistung itu sendiri merupakan kemampuan dasar yang harus dikuasai anak usia SD. Namun tidak ada keharusan bagi anak usia dini. Mengingat, anak usia dini berada pada masa golden age, dimana pada periode ini otak akan paling banyak menyerap apa yang dilihat dan didengar oleh anak (Hainstock, 1999:12). Tetapi orang tua menuntut guru untuk dapat mengajarkan anak calistung, karena ketika anak memasuki sekolah dasar diharuskan sudah mahir membaca menulis dan berhitung. Tidak sedikit sekolah dasar favorit yang menerapkan aturan anak yang mendaftar di SD itu sudah harus bisa membaca, menulis dan berhitung, sehingga, orang tua banyak berharap di TK maupun PAUD sudah mulai diajarkan tentang calistung.

Tuntutan yang diberikan terkadang dapat menjadi beban bagi anak, sehingga tak jarang anak meluapkan emosi negatifnya. Sebagian besar sumber stress siswa berasal dari masalah akademik. Hal tersebut serupa dengan pendapat Shahmohammadi (2011) yang menyatakan "Stress di bidang akademik pada anak muncul ketika harapan untuk meraih prestasi akademik meningkat, baik dari orang tua, guru ataupun teman sebaya. Harapan tersebut seringkali tidak 
sesuai dengan kemampuan yang mereka miliki"

Akan tetapi dengan adanya penyelenggaraan tes baca tulis di sekolah dasar juga menjadi memberatkan orang tua, di sisi lain itu menjadi sesuatu kewajiban. Mengapa demikian, karena orang tua tidak mempunyai pilihan lain, mau berbuat apa lagi jika memang untuk memasuki jenjang sekolah dasar itu di haruskan untuk bisa baca dan tulis. Orang tua mempunyai strategi tersendiri dengan memperkenalkan buku cerita dan membiasakan untuk membacakan buku cerita sebelum tidur, orang tua juga tidak memaksakan anak harus bisa tetapi minimal anak paham konsepnya saja. Untuk mengembangkan kemampuan baca tulis anak guru PAUD dan orang tua harus bisa mengedukasi anak, dimana untuk mengajarkan pada anak itu harus sesuai dengan usianya. Selain itu harus ada komunikasi antara orang tua dan guru mengenai strategi pengajaran calistung pada anak, itu menjadi mempermudah dalam pengajaran kepada anak. Hal ini serupa dengan sebuah survei memperlihatkan keberhasilan balita dalam tahapan literasi awal, seperti menulis namanya sendiri, membaca atau berinteraksi dengan buku, serta menghitung hingga bilangan 10 . Pemilihan buku juga harus disesuaikan dengan usia anak, orang tua dapat menggunakan media yang menarik seperti buku cerita bergambar (Dewi, 2012)

\section{Negosisasi Guru PAUD Terhadap Tes Baca Tulis di Sekolah Dasar}

Pada bagian sebelumnya, peneliti telah memaparkan mengenai dengan adanya penyelenggaran tes baca tulis di sekolah dasar menjadikan orang tua menuntut kepada pihak sekolah untuk mengajarkan calistung sebelum anak memasuki jenjang sekolah dasar. Mengingat dalam pengajaran pada anak usia dini itu lebih menekankan pada pembelajaran yang menyenangkan yaitu dengan melalui bermain, tentunya dalam hal mengembangkan kemampuan calistung pada anak. Oleh karena itu perlu adanya pola khusus dalam meningkatkan kemampuan membaca permulaan pada anak usia dini, yang dipengaruhi oleh beberapa faktor pendukung.

Negosiasi guru PAUD dibagi atas pemahaman dan upaya antisipasi guru PAUD dan pihak sekolah untuk mengajarkan calistung sebelum memasuki jenjang sekolah dasar. Sebagaian besar guru menyayangkan penyelenggaran tersebut, karena berdampak pada perkembangkan anak Serta sebagaimana yang tercantum pada Peraturan Menteri Pendidikan dan Kebudayaan Republik Indonesia Nomor 18 Tahun 2018 tentang Pengelolaan dan Penyelenggaraan Pendidikan, pada Pasal 9 ayat (1) disebutkan bahwa Pembelajaran dalam PAUD dilaksanakan dengan menggunakan pendekatan berpusat pada anak dalam konteks bermain sesuai dengan tingkat pencapaian perkembangan anak. Dhieni, dkk (2007: 5.18) mengungkapkan faktor-faktor tersebut ialah motivasi, lingkungan keluarga dan guru serta bahan bacaan. Salah satunya faktor disini berkaitan dengan komponen-komponen pembelajaran ialah guru. Guru sebagai objek utama dalam melaksanakan pembelajaran di PAUD atau TK. Kemampuan guru dalam memberikan pembelajaran 
akan sangat menentukan keberhasilan belajar.

Akan tetapi dengan adanya tuntutan orang tua terhadap guru PAUD juga dengan adanya penyelenggaran tes baca tulis di sekolah dasar, hal ini menjadikan guru PAUD harus mempunyai strategi tersendiri agar bisa mengajarkan calistung kepada anak usia dini, tentunya tidak terlepas dari perkembangan anak dan disesuaikan juga dengan usia anak.

Guru di sekolah PAUD atau TK mempunyai strategi tersendiri mengenai pengajaran calistung pada anak, yaitu dengan membiasakan setiap minggunya dibacakan cerita melalui cerita bergambar dan dengan mengajarkan calistung menggunakan metode cantol roudhoh. Dengan metode ini anak bukan diajarkan untuk membaca, tetapi untuk menumbuhkan minat dan gemar membaca pada anak, dan juga dalam pembelajaran membaca memlaui metode cantol roudhoh ini dengan upaya untuk memberikan pengaruh dalam kemampuan pengenalan membaca pada anak PAUD kelompok B (Yusniwati, 2012). Selain itu harus ada komunikasi antara guru dan orang tua mengenai metode yang diajarkan di sekolah dalam pengajaran calistung pada anak. Guru itu sebagai objek utama dalam melaksanakan pembelajaran di PAUD atau TK. Kemampuan guru dalam memberikan pembelajaran akan sangat menentukan keberhasilan belajar. Sebenarnya anak memiliki potensi, jika orang dewasa mampu menyediakan lingkungan yang baik bagi anak (Asmani, 2012).

\section{SIMPULAN}

Penanganan mengenai penyelanggaraan tes baca tulis di sekolah dasar, guru PAUD menerapkan metode cantol roudhoh merupakan salah satu bentuk penanganan yang dapat menjadi alternatif bagi lembaga PAUD. Dalam metode cantol roudhoh ini dapat dilakukan melalui metode ini anak bukan diajarkan untuk membaca, tetapi untuk menumbuhkan minat dan gemar membaca pada anak, dan memalui bercerita sambil bermain, sehingga anak merasa senang dan tidak tertekan ketika diberikan stimulus. Oleh karena itu dalam upaya guru PAUD disekolah dengan adanya metode ini bisa mempermudah anak dalam berliterasi.

\section{DAFTAR RUJUKAN}

Ananto, R. 2019. Peningkatan Kemampuan Literasi Dan Disposisi Matematis Siswa SMP/Mts Melalui Pendekatan Pembelajaran Realistic Mathematic Education. Skripsi. UIN Sunan Kalijaga Yogyakarta

Asmani, J. M. (2012). Tips Menjadi Guru Inspiratif, Kreatif dan Inovatif. Yogyakarta: Diva press

Basrowi dan Suwandi. 2008. Memahami Penelitian Kualitatif. Jakarta: Rineka Cipta

Depdiknas .2003. Undang-undang RI No.20 tahun 2003. Tentang sistem pendidikan nasional.

Desmita. (2012). Psikologi Perkembangan. Bandung: Remaja RoSDakarya.

Dewi, Ratna, A. (2012). Peningkatan Kemampuan Membaca Permulaan melalui Media Kartu Bergambar pada Anak Kelompok A di TK 
Masyitoh Kedungsari Kulon Progo. Skripsi. Yogyakarta: Universitas Negeri Yogyakarta Dhieni, N., dkk. (2007). Metode Pengembangan Bahasa. Jakarta: Universitas Terbuka

Fajriyah, L. (2018). Pengembangan Literasi Emergan Pada Anak Usia Dini. 1 (3) 2018, 165-172. DOI: 10.21070/picecrs.v1i3.1394

Hainstock, Elizabeth, G. 1999. Metode Pengajaran Montessori untuk Anak Prasekolah. Jakarta : Pustaka Delapratasa.

Hidayat, N. 2016. Implementasi Pendidikan Karakter Melalui Pembiasaan Di Pondok Pesantren Pabelan. JPSD Jurnal Pendidikan Sekolah Dasar. 2(1)

Hurlock, E. B. (1978). Perkembangan Anak. Jakarta: Erlangga.

Kuder, S. J. \& Hasit, C. (2002). Enhanching Literacy For All Students. USA: Pearson Education Inc.

Murtie, A (2013). Mengajari Calistung dengan Bermain. Jakarta : PT Gramedia Pustaka Utama

Peraturan Menteri Pendidikan dan Kebudayaan Republik Indonesia Nomor 18 Tahun 2018 tentang Pengelolaan dan Penyelenggaraan Pendidikan

Piaget, Jean. (1988). Antara Tindakan Dan Pikiran. Jakarta: PT. Gramedia

Pratiwi, E. (2015). Pembelajaran Calistung Pada Anak Usia Dini Antara Manfaat Akademik Dan Resiko Menghambat Kecerdasan Mental Anak. Prosiding Seminar Nasional Pendidikan. FKIP Universitas Muhamadiyah Ponorogo: Yogyakarta
Programme for International Student Assessment (PISA). (2009 dan 2012). Di akses pada 10 Maret 2019.https://www.oecd.org/pisa/k eyfindings/pisa-2012-resultsvolume-I.pdf

Progress in International Reading Literacy Study (PIRLS) (2011). Di unduh pada 10 Maret 2019. https://timssandpirls.bc.edu/pirls2 011/index.html

Santoso, T. (2011). Metode Membaca Secepat Kilat. Yogyakarta : pustaka Widyatama

Shahmohammadi, (2011). Students coping with stress at hight school level particulary at 11 th \& 12th grade. Jurnal social and behavioral sciences. 30, 395-401

Sujiono N.Y. (2013). Konsep Dasar Pendidikan Anak Usia Dini.Jakarta:PT Indeks

Suwardi. (2007). Manajemen Pembelajaran. Surabaya: PT temprina Media Grafika.

UNESCO. (2013). Treasure Within : Report To UNESCO of The International Commission on Education for The Twenty-first Century. France : United Nations Educational, Scientific and Cultural Organization.

Watson, R \& Wildy, H. (2014). Pedagogical practice of early childhood teacher: Explicit enhancement of student's literacy. Australian Journal of Early Childhood, 39(2),82-90.

World Economic Forum. (2016). The Global Competitiveness Report 2016-2017. Retrieved from World Economic Forum Website: https://www.weforum.org/reports/ the-global-competitivenessreport-2016- 2017-1 
Yusniwati. (2012). Peningkatan Kemampuan Membaca Awal pada Anak Kelas A dengan Metode Cantol Roudhoh di TK Trisula Perwari Sragen Tahun Ajaran 2011/2012. Skripsi. Surakarta : Universitas Muhammadiyah Surakarta.

Yusuf, A. M. (2014). Metode Penelitian Kuantitatif Kualitatif dan Penelitian Gabungan. Jakarta: Prenda Media Group 